Rafał Gałka

Student Uniwersytetu Pedagogicznego im. Komisji Edukacji Narodowej w Krakowie

\title{
Fundusze unijne $w$ realizacji zadań gminy na przykładzie Kalwarii Zebrzydowskiej w latach 2007-2013
}

https://doi.org/10.25312/2391-5110.14/2019_06rg

\section{Streszczenie}

Fundusze unijne zaczęły oddziaływać na życie Polaków z chwilą wstąpienia Polski do Unii Europejskiej. Na mocy traktatu akcesyjnego od 1 maja 2004 roku Polska została jednym z członków UE. W latach 2007-2013 Polska korzystała ze środków unijnych z: Europejskiego Funduszu Rozwoju Regionalnego, Europejskiego Funduszu Społecznego, Funduszu Spójności, Europejskiego Funduszu Rolnego na rzecz Rozwoju Obszarów Wiejskich, Europejskiego Funduszu Morskiego i Rybackiego. Artykuł przedstawia procentowy udział funduszy unijnych w realizacji wybranych zadań w stosunku do środków pochodzących z budżetu gminy. Opisano gminę jako jednostkę zdecentralizowanego samorządu terytorialnego, wyjaśniając jej odpowiedzialność za sprawy o zasięgu lokalnym. Przedstawiono zarys budżetu gminy i jego części składowe, uwzględniając aspekty samodzielności finansowania gmin. Podkreślono, iż wykonywanie zadań zleconych lub własnych przez gminę jest wyrazem samodzielności. Poruszono aspekt wykorzystania funduszy unijnych, które wraz z przystąpieniem Polski do UE stały sięźródłem dochodów gminy. Opisano fundusze unijne mające udział w budżecie gminy Kalwaria Zebrzydowska w latach 2007-2013. Wybierając ten okres, kierowano się głównie rozliczeniem wszystkich przedsięwzięć. Dzięki pozyskanym funduszom europejskim gmina Kalwaria Zebrzydowska mogła zrealizować wiele projektów, które miały realne znaczenie w życiu jej mieszkańców.

Słowa kluczowe: Unia Europejska, fundusze unijne, gmina, administracja, obywatel, mieszkaniec, EFRR, EFS, FS, EFRROW, EFMR 


\title{
European Union funds in the implementation of municipal tasks: The example of Kalwaria Zebrzydowska (2007-2013) Summary
}

\begin{abstract}
Poland joined the European Union on 1 May 2004. Since then EU funds have impacted on the lives of Poles. Between 2007-2013 Poland benefitted from various European Union funds including the European Regional Development Fund, the European Agricultural Fund for Rural Development, the European Maritime and Fisheries Fund. This article discusses EU funds, included in the commune budget, that are used in the implementation of selected tasks. The commune is described as a unit of local government. The scope of its responsibility for local matters is outlined. The budget of the commune is summarised. The commune's level of financial autonomy is noted. The performance of tasks commissioned by the commune is highlighted as an expression of independence. EU funds are shown to be a constant source of income for the commune. EU funds received by the Kalwaria Zebrzydowska commune are listed as a proportion of the commune's budget from 2007 to 2013. In this period EU funding was distributed. EU funds allowed the Kalwaria Zebrzydowska commune to implement many projects that impacted on the lives of residents.
\end{abstract}

Keywords: European Union, EU funds, commune, administration, citizen, resident, ERDF, ESF, CF, EAFRD, EMFF

\section{Wprowadzenie}

Potencjał finansowy wywiera istotny wpływ na prawidłowe funkcjonowanie jednostek samorządu terytorialnego, a przede wszystkim na ich rozwój. Zmiany, które dokonują się w zarządzaniu nimi, są niezmiernie istotne z punktu widzenia rozwoju, co przekłada się na lokalną gospodarkę i funkcjonowanie jej mieszkańców.

Polska została członkiem Unii Europejskiej 1 maja 2004 roku. Członkostwo to ma ogromny wpływ na rozwój gospodarczy kraju z uwagi na obowiązek przestrzegania surowych regulacji i niejednokrotnie wygórowanych wymogów unijnych. W latach 2007-2013 Polska korzystała ze środków unijnych z Europejskiego Funduszu Rozwoju Regionalnego, Europejskiego Funduszu Społecznego, Funduszu Spójności, Europejskiego Funduszu Rolnego na rzecz Rozwoju Obszarów Wiejskich oraz Europejskiego Funduszu Morskiego i Rybackiego. Również Kalwaria Zebrzydowska, tak jak każda inna polska miejscowość, podjęła starania, aby w jak najlepszy sposób wykorzystać środki unijne do realizacji istotnych zadań publicznych - zarówno za pośrednictwem projektów infrastrukturalnych, jak i społecznych.

Celem niniejszego artykułu jest zbadanie, jaki był procentowy udział funduszy unijnych w latach 2007-2013 w realizacji wybranych zadań w stosunku do środków pochodzących z budżetu gminy. Autor, analizując udostępnione przez urząd gminy dane finansowe, zastanowi się nad proporcjami w tym zakresie i dzieląc się własnymi spostrzeżeniami, zaproponuje pewne, dość ogólne (z uwagi na objętość opracowania) wnioski. Posłuży to udowodnieniu tezy, iż gminy, takie jak Kalwaria Zebrzydowska, w szerokim zakresie wykorzystują swój potencjał, jakim jest przede wszystkim położenie geograficzne, do bardziej efektywnej, biorąc pod 
uwagę łączenie środków własnych z funduszami pochodzącymi z Unii Europejskiej, realizacji zadań publicznych. Wykorzystana w pracy metoda badawcza to głównie analiza dokumentów, a także map dotacji i opisów projektów realizowanych w latach 2007-2013. Wybierając ten okres, autor kierował się głównie jego ,zamknięciem” i związanym z tym faktem końcowym rozliczeniem wszystkich podejmowanych we wskazanych latach przedsięwzięć. Umożliwiło to bowiem holistyczną analizę zrealizowanych już dochodów i wydatków.

Artykuł składa się sześciu części. W pierwszej omówiono gminę jako podstawową jednostkę samorządu terytorialnego i scharakteryzowana jej zadania, a w następnej omówiono krótko sam budżet. Trzecia część skupia się na funduszach unijnych, które mogą być źródłem dochodów gminy. Czwarta natomiast poświęcona jest bezpośrednio gminie Kalwarii Zebrzydowskiej i zawiera charakterystykę jej budżetu w latach 2007-2013 z uwzględnieniem środków pochodzących z Unii Europejskiej. Na końcu umieszczono podsumowanie zawierające wnioski autora.

\section{Gmina jako jednostka zdecentralizowanego samorządu terytorialnego}

„W aktualnym systemie prawnym Rzeczpospolitej Polskiej głównym ogniwem samorządu terytorialnego jest gmina”. . Również Konstytucja RP w art. 164 ust. 1 stwierdza, iż ,podstawową jednostką samorządu terytorialnego jest gmina"2. Wyżej wymienione stwierdzenia pociągają za sobą szereg konsekwencji, między innymi: zaspokajanie potrzeb jednostki, która żyje, pracuje i uczestniczy w życiu lokalnym na danym obszarze, co przedstawia Ustawa z dnia 8 marca $1990 \mathrm{r}$. o samorządzie gminnym w art. 7, precyzując, iż: ,zaspokajanie zbiorowych potrzeb wspólnoty

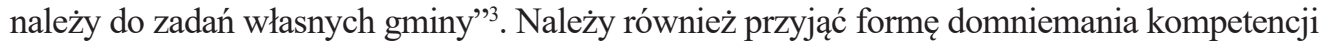
z uwagi na pytania i wątpliwości dotyczące zadań, które ma wykonać dana jednostka. Jest to zawarte w tej samej ustawie, w art. 6 ust. 1: „do zakresu działania gminy należą wszystkie sprawy publiczne o znaczeniu lokalnym, niezastrzeżone ustawami na rzecz innych podmiotów"4.

Gmina jest więc podstawową jednostką samorządu terytorialnego, odpowiedzialną za sprawy mające zasięg lokalny, która ma za zadanie zaspokoić podstawowe potrzeby wspólnoty samorządowej. ,Rozczłonkowanie terytorium państwa i wydzielenie wyodrębnionych jednostek terytorialnych dla działalności administracyjnej" ${ }^{5}$ - to definicja podziału terytorialnego, który ma ułatwić kontakt obywatela z organem władzy terenowej. Z mocy prawa każdy mieszkaniec danej gminy należy do swoistego „zrzeszenia”, które wypełnia zadania administracyjne. Przynależność do gminy jest więc obligatoryjna i wiąże się z faktem zamieszkiwania na danym terytorium.

${ }^{1}$ S. Wykrętowicz, Samorzad w Polsce istota, formy, zadania, Wydawnictwo Wyższej Szkoły Bankowej, Poznań 2008, s. 163.

2 Art. 164 ust. 1 Konstytucji Rzeczypospolitej Polskiej z dnia 2 kwietnia 1997 r. r., tekst jedn. Dz.U. z 2009 r. nr 114, poz. 946 - dalej Konstytucja RP.

3 Art. 7 Ustawy z dnia 8 marca 1990 r. o samorządzie gminnym, tekst jedn. Dz.U. z 2019 r., poz. 506, $1309,1571,1696,1815$ - dalej ustawa o samorządzie gminnym.

${ }^{4}$ Tamże, art. 6, ust. 1.

5 E. Zieliński, Samorząd terytorialny w Polsce, Dom Wydawniczy Elipsa, Warszawa 2004, s. 14. 
Gmina wykonuje zadania publiczne własne i zlecone. Artykuł 163 Konstytucji RP przedstawia zarys kompetencji, które ma w swojej władzy gmina: „samorząd terytorialny wykonuje zadania publiczne niezastrzeżone przez Konstytucję lub ustawy dla organów innych władz publicznych"6. Oczywiście są one wykonywane na własną odpowiedzialność przez gminę, a czyniąc to, daje ona do zrozumienia, że jest samodzielnym podmiotem, a państwo może ingerować tylko w przypadkach ujętych w ustawach, natomiast ochrona samodzielności gminy jest gwarantowana przez sąd, na co wskazuje art. 165 ust. 2: „samodzielność jednostek samorządu terytorialnego podlega ochronie sądowej"7.

Najbardziej istotnym artykułem formułującym domniemanie kompetencji gminy w sprawach publicznych o aspekcie lokalnym jest art. 6 ustawy o samorządzie gminnym (zakres działania gminy): „1. Do zakresu działania gminy należą wszystkie sprawy publiczne o znaczeniu lokalnym, niezastrzeżone ustawami na rzecz innych podmiotów. 2. Jeżeli ustawy nie stanowią inaczej, rozstrzyganie w sprawach, o których mowa w ust. 1, należy do gminy"8. Domniemanie stanowi regułę, na której oparty jest podział zadań w zakresie publicznym, mających znaczenie lokalne. Jest ona również dyrektywą interpretacyjną w przypadku, gdyby miały powstać spory kompetencyjne w tym zakresie. Podział na zadania własne i zlecone dla samorządu terytorialnego zawarty jest w Konstytucji RP, a dokładniej w art. 166 ust. 1: „Zadania publiczne służące zaspokajaniu potrzeb wspólnoty samorządowej są wykonywane przez jednostkę samorządu terytorialnego jako zadania własne" . Natomiast w ust. 2 ustawa zasadnicza wskazuje, że: ,Jeżeli wynika to z uzasadnionych potrzeb państwa, ustawa może zlecić jednostkom samorządu terytorialnego wykonywanie innych zadań publicznych. Ustawa określa tryb przekazywania i sposób wykonywania zadań zleconych"10.

Zadania własne to zaspokojenie potrzeb wspólnoty, natomiast zlecone dotyczą zakresu administracji rządowej oraz organizacji i przygotowań związanych z wyborami lub referendami. Oba rodzaje zadań mogą mieć znamiona obowiązkowe, jeżeli są obligowane przez ustawę do ich wykonania, a także dobrowolne. Dobrowolne zadania z zakresu administracji rządowej gmina może wykonywać na podstawie porozumień. Różnica pomiędzy nimi tkwi w „delegacji”, własne zadania gmina wykonuje we własnym imieniu i na własną odpowiedzialność i w związku z tym podlega kontroli jedynie z punktu widzenia legalności. Natomiast zadania zlecone wykonywane są na podstawie ustawy lub porozumienia, a zlecający zastrzega sobie prawo do ich ściślejszej kontroli.

\section{Budżet gminy}

Dochodami budżetu gminy nazywamy środki finansowe przekazane w sposób bezzwrotny od podmiotów gospodarczych, a także osób fizycznych lub finanse otrzymane pod postacią dotacji lub subwencji, z przeznaczeniem na realizację konkretnych celów na rzecz zaspo-

\footnotetext{
${ }^{6}$ Art. 163 Konstytucji RP.

Tamże, art. 165 ust. 2.

8 Art. 6 ustawy o samorządzie gminnym.

9 Art. 166 ust. 1 Konstytucji RP.

10 Tamże, art. 166, ust. 2.
} 
kojenia potrzeb mieszkańców danej gminy. W Ustawie z dnia 13 listopada 2003 roku o dochodach jednostek samorządu terytorialnego ${ }^{11}$ zawarte są zasady gromadzenia dochodów i przekazywania subwencji czy dotacji.

Podstawą wykonywania zadań zleconych lub własnych przez gminę jest jej budżet, który jest wyrazem samodzielności tej jednostki. Samodzielność wyznaczona jest przez przepisy kilku aktów prawnych: Konstytucji RP, Europejskiej Karty Samorządu Lokalnego ${ }^{12}$, ustaw zwykłych, ustawy o samorządzie gminnym, ustawy o finansach publicznych i ustawy o dochodach jednostek samorządu terytorialnego. Artykuł 167 ust. 1 ustawy zasadniczej brzmi: „Jednostkom samorządu terytorialnego zapewnia się udział w dochodach publicznych odpowiednio do przypadających im zadań"13. Trybunał Konstytucyjny ${ }^{14}$ odnosi się do przytoczonego artykułu, twierdząc, iż należy zachować proporcję między wysokością dochodów a zakresem zadań jednostek samorządu terytorialnego.

Można rozróżnić dwa aspekty samodzielności finansowania gmin: dochodowy oraz wydatkowy. Jeśli chodzi o aspekt dochodowy, to bardzo ważną sprawą jest polityka podatkowa. Jest to świadome działanie podejmowane przez samorząd terytorialny, które ma zamierzony cel i dąży do uzyskania pożądanego efektu. Ustawa z dnia 13 listopada 2003 r. o dochodach jednostek samorządu terytorialnego ${ }^{15}$ określa w Polsce źródła dochodów dla jednostek samorządu terytorialnego. Z kolei aspekt wydatkowy to prawo do decydowania przez jednostki samorządu terytorialnego o rodzaju zadań i sposobie ich wykonywania, realizowaniu ich, a także zakresie ponoszonych wydatków, które zostały przeznaczone na ich realizację. Istnieje również podział na pośredni i bezpośredni sposób oddziaływania państwa na wydatki samorządu. Ten pierwszy to tzw. regulowanie sfery działania samorządu, a drugi nakaz ponoszenia określonych wydatków, ustalenie limitów wydatków, zakazanie określonych wydatków. Warto podkreślić, że decentralizacja władzy publicznej wiąże się nierozerwalnie z efektywnym i sprawiedliwym podzieleniem środków finansowych.

\section{Fundusze Unii Europejskiej źródłem dochodów gminy}

Polska od 1 maja 2004 roku jest członkiem Unii Europejskiej. Fundusze pochodzące z UE odgrywają ważną rolę, zwłaszcza w ostatnich latach, gdyż są znacznym wsparciem dla ograniczonych budżetów własnych wielu podmiotów, również administracji publicznej. Realizowane w gminach projekty charakteryzują się zróżnicowaniem, a jest to zależne przede wszystkim od rodzaju gminy, jej położenia geograficznego czy po prostu specyficznych potrzeb jej mieszkańców. Nie da się zaprzeczyć, że udział środków finansowych pochodzących z UE w dochodach gmin jest przejawem aktywności ze strony władzy w pozyskiwaniu

${ }^{11}$ Ustawa z dnia 13 listopada 2003 r. o dochodach jednostek samorządu terytorialnego, tekst jedn. Dz.U. z 2020 r., poz. 23 - dalej ustawa o dochodach jednostek samorządu terytorialnego.

${ }_{12}$ E. Kornberger-Sokołowska (red. nauk.), J. Zdanukiewicz, R. Cieślak, Jednostki samorzadu terytorialnego jako beneficjenci środków europejskich, Wolters Kluwer Polska, Warszawa 2012, s. 21.

13 Art. 167 ust. 1 Konstytucji RP.

${ }_{14}$ Wyrok Trybunału Konstytucyjnego z dnia 16 marca 1999 r., K35/98, Orzecznictwo Trybunału Konstytucyjnego 1999, nr 3, poz. 37.

${ }^{15}$ Ustawa o dochodach jednostek samorządu terytorialnego. 
Środków finansowania zadań z zewnątrz. Najważniejszym celem ubiegania się o te środki wydaje się potrzeba zapewnienie zrównoważonego rozwoju. Do grupy największych funduszy pochodzących z budżetu unijnego, z których korzystać mogą polskie gminy, zaliczyć można: fundusze strukturalne, Fundusz Spójności i Europejski Fundusz Rolny na rzecz Rozwoju Obszarów Wiejskich.

Narzędziem pomocy Unii Europejskiej dla Polski w latach 2007-2013 była realizacja Narodowej Strategii Spójności. Polska korzystała w tym okresie z pięciu funduszy w ramach tzw. polityki spójności:

1) Europejskiego Funduszu Rozwoju Regionalnego ${ }^{16}$,

2) Europejskiego Funduszu Społecznego ${ }^{17}$,

3) Funduszu Spójności ${ }^{18}$,

4) Europejskiego Funduszu Rolnego na rzecz Rozwoju Obszarów Wiejskich ${ }^{19}$,

5) Europejskiego Funduszu Morskiego i Rybackiego ${ }^{20}$.

Fundusze strukturalne są elementami polityki strukturalnej Unii Europejskiej, a ich zadaniem jest restrukturyzacja i modernizacja gospodarki w krajach Unii ${ }^{21}$. Wpływa to na spójność ekonomiczną i społeczną. Tego typu fundusze kierowane są głównie do sektorów gospodarki i regionów niebędących w stanie dorównać pozostałym w poziomie rozwoju. Celem tej polityki jest zmniejszenie różnic ekonomicznych i społecznych mających miejsce w Unii Europejskiej. Na fundusze strukturalne w okresie 2007-2013 składały się: Europejski Fundusz Rozwoju Regionalnego, Europejski Fundusz Społeczny, Fundusz Spójności, Europejski Fundusz Morski i Rybacki, Europejski Fundusz Rolny na rzecz Rozwoju Obszarów Wiejskich.

Celem Europejskiego Funduszu Rozwoju Regionalnego (EFRR) było zmniejszanie różnic w poziomie rozwoju regionów na terenie Unii Europejskiej oraz wzmacnianie spójności gospodarczej, społecznej i terytorialnej. Z funduszu tego pochodzi m.in. wsparcie inwestycji infrastrukturalnych i produkcyjnych, a także małych i średnich przedsiębiorstw.

Europejski Fundusz Społeczny (EFS) ${ }^{22}$ ma na celu walkę z bezrobociem w krajach członkowskich Unii Europejskiej. Pieniądze z niego miały umożliwić kształcenie się i znalezienie zatrudnienia. Współfinansowana była z niego pomoc dla regionów i grup społecznych,

${ }^{16}$ Rozporządzenie (WE) nr 1080/2006 Parlamentu Europejskiego i Rady z dnia 5 lipca 2006 r. w sprawie Europejskiego Funduszu Rozwoju Regionalnego i uchylające rozporządzenie (WE) nr 1783/1999.

${ }^{17}$ Rozporządzenie (WE) nr 1081/2006 Parlamentu Europejskiego i Rady z dnia 5 lipca 2006 r. w sprawie Europejskiego Funduszu Społecznego i uchylające rozporządzenie (WE) nr 1784/1999.

18 A. Szymańska, Fundusze unijne i europejskie 2007-2013 dla mieszkańców obszarów wiejskich, Wydawnictwo Placet, Warszawa 2008, s. 9.

19 Rozporządzenie Parlamentu Europejskiego i Rady (UE) nr 1305/2013 z dnia 17 grudnia 2013 r. w sprawie wsparcia rozwoju obszarów wiejskich przez Europejski Fundusz Rolny na rzecz Rozwoju Obszarów Wiejskich (EFRROW) i uchylające rozporządzenie Rady (WE) nr 1698/2005.

${ }^{20}$ Rozporządzenie Parlamentu Europejskiego i Rady (UE) nr 508/2014 z dnia 15 maja 2014 r. w sprawie Europejskiego Funduszu Morskiego i Rybackiego oraz uchylające rozporządzenia Rady (WE) nr 2328/2003, (WE) nr 861/2006, (WE) nr 1198/2006 i (WE) nr 791/2007 oraz rozporządzenie Parlamentu Europejskiego i Rady (UE) nr 1255/2011.

${ }_{21}$ R. Cieślak, J. Kordasiewicz, Fundusze unijne 2007-2013. Poradnik przedsiębiorcy, Wydawnictwo Unimex, Wrocław 2007, s. 21.

22 A. Szymańska, Fundusze unijne i europejskie 2007-2013 dla samorzadu terytorialnego, Wydawnictwo Placet, Warszawa 2008, s. 294. 
a w szczególności dla osób zagrożonych ubóstwem oraz młodych ludzi wchodzących na rynek pracy.

Fundusz Spójności jest funduszem przeznaczonym dla państw członkowskich Unii Europejskiej, których dochód narodowy brutto (DNB) na mieszkańca wynosi mniej niż 90\% średniej w Unii. Ma on za zadanie zredukowanie różnic społecznych i gospodarczych, ale również promowanie zrównoważonego rozwoju za pomocą tworzenia dużych inwestycji w zakresie infrastruktury transportowej i ochrony środowiska.

Celem Europejskiego Funduszu Morskiego i Rybackiego jest wspieranie restrukturyzacji rybołówstwa państw członkowskich Unii Europejskiej, a także ułatwienie im dostępu do finansowania projektów, które tworzą nowe miejsca pracy czy podnoszą jakość życia społeczności nadmorskich oraz zróżnicowanie lokalnej gospodarki.

Europejski Fundusz Rolny na rzecz Rozwoju Obszarów Wiejskich (EFRROW) ${ }^{23}$ jest funduszem, który wspiera politykę na terenie Unii Europejskiej pod względem rozwoju obszarów wiejskich. W jego ramach zostały zorganizowane programy rozwoju obszarów wiejskich na terenie wszystkich państw członkowskich Unii Europejskiej. Program opracowywany jest przez państwa członkowskie we współpracy z Komisją Europejską. Polega to na przygotowaniu strategii rozwoju obszarów wiejskich, a także określeniu priorytetów w strategiach danego kraju.

Europejski Fundusz Rolny na rzecz Rozwoju Obszarów Wiejskich jest wydawany w państwach członkowskich za pośrednictwem Programów Rozwoju Obszarów Wiejskich. Program Rozwoju Obszarów Wiejskich ${ }^{24}$ jest programem wdrażanym przez każde państwo członkowskie, a jego zadaniem jest poprawa jakości życia mieszkańców obszarów wiejskich. W Polsce projekty PROW były realizowane w latach 2004-2006, 2007-2013, a także 2014-2020. Polegały one na wspieraniu finansowym terenów wiejskich w Polsce za pomocą wdrażania różnych działań, mających za zadanie wspieranie rozwoju tych terenów. Programy, które zostały sfinalizowane, pomogły rolnikom w zakupie maszyn i sprzętu rolniczego, a także zmodernizowaniu gospodarstw. Występują również tak zwane pakiety ptasie i botaniczne, które są ważną pomocą jako dopłaty rolno-środowiskowe.

\section{Fundusze unijne w budżecie gminy Kalwaria Zebrzydowska w latach 2007-2013}

Kalwaria Zebrzydowska to miasto zamieszkane przez 19835 mieszkańców ${ }^{25}$, o powierzchni zajmującej 5,5 km². Położone jest na południu Polski, w województwie małopolskim. Jest przykładem gminy miejsko-wiejskiej.

W celu lepszego i efektywniejszego wykorzystania funduszy unijnych na danym terenie - inwestując w najbardziej opłacalne aktywa, przynoszące zysk dla gminy - stosuje się

${ }^{23}$ Rozporządzenie Rady (WE) nr 1698/2005 z dnia 20 września 2005 r. w sprawie wsparcia rozwoju obszarów wiejskich przez Europejski Fundusz Rolny na rzecz Rozwoju Obszarów Wiejskich (EFRROW).

${ }^{24}$ A. Szymańska, Fundusze unijne i europejskie 2007-2013 dla mieszkańców..., dz. cyt., s. 39.

${ }^{25}$ Główny Urząd Statystyczny, Powierzchnia i ludność w przekroju terytorialnym w $2013 \mathrm{r}$., https:// stat.gov.pl/obszary-tematyczne/ludnosc/ludnosc/powierzchnia-i-ludnosc-w-przekroju-terytorialnym-w2013-r-, 7,10.html [dostęp: 28.05.2018]. 
analizę $\mathrm{SWOT}^{26}$ (z ang. strengths - mocne strony, weaknesses - słabe strony, opportunities szanse, threats - zagrożenia). Jest to powszechna metoda diagnozy pozycji rozwojowej obszaru. Została ona także zastosowana podczas diagnozy pozycji rozwojowej gminy Kalwaria Zebrzydowska - zawarto ją również w planie rozwoju lokalnego ${ }^{27}$. Analiza ukazuje mocne i słabe strony, a także szanse i zagrożenia, które mogą pośrednio czy bezpośrednio wpłynąć na pozycję rozwojową gminy. Dane zawarte w tabeli 1 skupiają się na czynnikach wewnętrznych (mocne strony i szanse), na wykorzystaniu historii miejscowości (tradycje rzemiosła czy sanktuarium pasyjno-maryjne, ściągające rzesze pielgrzymów), natomiast szansą jest pozyskiwanie funduszy zewnętrznych, w tym pochodzących z Unii Europejskiej, i wykorzystanie ich przy zagospodarowaniu przestrzennym oraz poszukiwaniu innych rynków zbytu. Czynniki zewnętrzne (słabe strony i zagrożenia) skupiają się głównie na słabo rozwiniętej infrastrukturze drogowej i służbie komunalnej, ale także na zagrożeniach wynikających z emigracji młodych ludzi i z patologii społecznej.

Tabela 1. Analiza SWOT - plan rozwoju lokalnego gminy Kalwaria Zebrzydowska 2004-2013

\begin{tabular}{|c|c|}
\hline Mocne strony & Słabe strony \\
\hline $\begin{array}{l}\text { 1. Położenie geograficzne (bliskość Krakowa, droga } \\
\text { krajowa) } \\
\text { 2. Sanktuarium oo. bernardynów wpisane na listę UNESCO } \\
\text { 3. Ruch pielgrzymkowo-turystyczny } \\
\text { 4. Tradycje rzemiosła kalwaryjskiego } \\
\text { 5. Rozwinięte szkolnictwo w zakresie szkół średnich } \\
\text { 6. Opieka zdrowotna (całodobowa) }\end{array}$ & $\begin{array}{l}\text { 1. Słabo rozwinięta infrastruktura kanalizacyjna } \\
\text { 2. Brak własnych ujęć wody } \\
\text { 3. Brak obwodnicy drogowej } \\
\text { 4. Słaba infrastruktura drogowa } \\
\text { 5. Słabe zaplecze sportowo-rekreacyjne } \\
\text { 6. Brak wysypiska śmieci } \\
\text { 7. Brak programu segregacji odpadów } \\
\text { 8. Słaba infrastruktura turystyczna } \\
\text { 9. Rozdrobnienie gospodarstw rolnych }\end{array}$ \\
\hline Szanse & Zagrożenia \\
\hline $\begin{array}{l}\text { 1. Pozyskiwanie funduszy zewnętrznych przy odpowied- } \\
\text { nim zabezpieczeniu środków własnych } \\
\text { 2. Wykorzystanie odłogów w celach turystyczno-rekreacyj- } \\
\text { nych (ujęcie w planie zagospodarowania przestrzennego) } \\
\text { 3. Pozyskiwanie nowych rynków zbytu } \\
\text { 4. Zatwierdzony plan zagospodarowania przestrzennego } \\
\text { dla miasta i gminy Kalwaria Zebrzydowska }\end{array}$ & $\begin{array}{l}\text { 1. Niestabilne przepisy podatkowe } \\
\text { 2. Zwiększające się bezrobocie (emigracja młodych) } \\
\text { 3. Słaba kondycja rzemiosła } \\
\text { 4. Zagrożenie patologią społeczną }\end{array}$ \\
\hline
\end{tabular}

Źródło: Plan rozwoju gminy Kalwaria Zebrzydowska 2004-2013, http://kalwaria-zebrzydowska.pl/dokumenty/plan rozwoju lokalnego.pdf [dostęp: 1.05.2019].

Mając na celu zbadanie, jak duży udział miały fundusze Unii Europejskiej w dochodach bieżących i majątkowych gminy, przeanalizowano dane z uchwał budżetowych z lat 2007-2013 (tabele 2 i 3).

${ }^{26}$ R. Tylińska, Analiza SWOT instrumentem w planowaniu rozwoju, Wydawnictwa Szkolne i Pedagogiczne, Warszawa 2005, s. 7.

27 Plan rozwoju gminy Kalwaria Zebrzydowska 2004-2013, http://kalwaria-zebrzydowska.pl/dokumenty/plan_rozwoju_lokalnego.pdf [dostęp: 1.05.2019]. 
Tabela 2. Udział funduszy Unii Europejskich w dochodach bieżących gminy Kalwaria Zebrzydowska w latach 2007-2013

\begin{tabular}{|c|c|c|c|}
\hline Rok & $\begin{array}{c}\text { Dochody bieżące } \\
(\mathbf{z})\end{array}$ & $\begin{array}{c}\text { W tym ze środków pochodzących } \\
\text { z budżetu UE (zł) }\end{array}$ & $\begin{array}{c}\text { Procentowy udział środków unijnych } \\
\text { w dochodach bieżących (\%) }\end{array}$ \\
\hline 2007 & 34089011,00 & Brak danych & Brak danych \\
\hline 2008 & 36635308,00 & Brak danych & Brak danych \\
\hline 2009 & 42260576,00 & Brak danych & 0,97 \\
\hline 2010 & 41529925,59 & 402102,59 & 0,60 \\
\hline 2011 & 42198025,94 & 269947,94 & 0,40 \\
\hline 2012 & 47221624,22 & 198039,22 & 0,30 \\
\hline 2013 & 48435994,00 & 146049,00 & \\
\hline
\end{tabular}

Źródło: opracowanie własne na podstawie uchwał budżetowych gminy Kalwaria Zebrzydowska, „Biuletyn Informacji Publicznej Urzędu Miasta Kalwarii Zebrzydowskiej”, https://bip.malopolska.pl/umkalwariazebrzydowska [dostęp: 28.05.2018].

Tabela 3. Udział funduszy Unii Europejskich w dochodach majątkowych gminy Kalwaria Zebrzydowska w latach 2007-2013

\begin{tabular}{|c|c|c|c|}
\hline Rok & $\begin{array}{c}\text { Dochody } \\
\text { majątkowe (zł) }\end{array}$ & $\begin{array}{c}\text { W tym ze środków pochodzących } \\
\text { z budżetu UE (zł) }\end{array}$ & $\begin{array}{c}\text { Procentowy udział środków unijnych } \\
\text { w dochodach majątkowych (\%) }\end{array}$ \\
\hline 2010 & 427551,00 & 427551,00 & 100,0 \\
\hline 2011 & 300000,00 & 0,00 & 0,0 \\
\hline 2012 & 1300000,00 & 0,00 & 0,0 \\
\hline 2013 & 2588500,00 & 536500,00 & 20,7 \\
\hline
\end{tabular}

Źródło: opracowanie własne na podstawie uchwał budżetowych gminy Kalwaria Zebrzydowska, „Biuletyn Informacji Publicznej Urzędu Miasta Kalwarii Zebrzydowskiej”, https://bip.malopolska.pl/umkalwariazebrzydowska [dostęp: 28.05.2018].

Jak wynika z tabeli 2, udział funduszy Unii Europejskiej w dochodach bieżących gminy Kalwaria Zebrzydowska był niewielki - kształtował się poniżej 1\%, a w latach 2010-2013 jeszcze zmniejszał. Niestety, do 2010 roku w uchwałach budżetowych nie wskazywano środków pochodzących z budżetu UE, stąd nie można ocenić, jak wyglądał długoterminowy trend w tym zakresie. Natomiast z tabeli 3 można wywnioskować, iż udział funduszy europejskich w dochodach majątkowych gminy był bardzo rozbieżny. W roku 2010 udział środków unijnych równy był aż 100\%, a kolejne lata (2011 i 2012) nie przyniosły w ogóle dochodów. W roku 2013 środki pochodzące z budżetu UE wzrosły do ponad 0,5 mln zł, czyli do 20,7\% dochodów majątkowych gminy. To, że udział funduszy unijnych w dochodach majątkowych jest znacznie większy niż w dochodach bieżących, jest logiczne, biorąc pod uwagę fakt, że są to fundusze o znaczeniu inwestycyjnym. Wskazuje to, że udział funduszy pochodzących z Unii Europejskiej nie jest dochodem stałym, a cyklicznym i nierównomiernym. Dlatego też istnieje coroczna potrzeba uchwalania na dany rok budżetowy budżetu, jakim dysponuje gmina, oraz zaplanowania, na jakie dziedziny życia może przeznaczyć najwięcej funduszy lub z wykonania jakich zadań musi całkowicie zrezygnować bądź odroczyć je na inny termin, na przykład na kolejny rok budżetowy. Niestety, mniejsze miejscowości, jak omawiana Kalwaria Zebrzydowska, muszą liczyć 
się z tym, iż mają bardziej ograniczony budżet niż gminy o większym zaludnieniu czy finansach własnych oraz pochodzących z dotacji. Jest to największa bariera i ograniczenie rozwoju przy decentralizacji administracji publicznej.

W latach 2007-2013 dzięki współfinansowaniu z funduszy strukturalnych Unii Europejskiej na terenie gminy Kalwaria Zebrzydowska zostały zrealizowane następujące projekty:

1) „Budowa hali sportowej z zapleczem szatniowo-technicznym w miejscowości Kalwaria Zebrzydowska",

2) „Pomóż sobie. Program aktywizacji społecznej i zawodowej bezrobotnych w gminie Kalwaria Zebrzydowska",

3) „Przeciwdziałanie wykluczeniu cyfrowemu na terenie gminy Kalwaria Zebrzydowska”,

4) „Od bariery po sukces!",

5) „Możesz więcej”,

6) „Budowa sali gimnastycznej przy Zespole Szkół nr 3 w Przytkowicach”.

Tabela 4. Wartość projektów realizowanych przy wsparciu funduszy strukturalnych UE w gminie Kalwaria Zebrzydowska w latach 2007-2013

\begin{tabular}{|c|c|c|c|c|}
\hline Lp. & Wartość projektu (zł) & $\begin{array}{c}\text { Dofinansowanie z UE } \\
(\mathbf{z})\end{array}$ & Wkład własny gminy (zł) & $\begin{array}{c}\text { Stopa współfinansowa- } \\
\text { nia z UE (\%) }\end{array}$ \\
\hline 1 & 5741496,62 & 4601496,62 & 1140000,00 & 80,14 \\
\hline 2 & 1326014,20 & 1127112,07 & 198902,13 & 85,00 \\
\hline 3 & 1197890,00 & 1018206,50 & 179683,50 & 85,00 \\
\hline 4 & 746046,96 & 634139,92 & 111907,04 & 85,00 \\
\hline 5 & 363660,00 & 309111,00 & 54549,00 & 85,00 \\
\hline 6 & 2472438,46 & 86352,65 & 2386085,81 & 3,49 \\
\hline Suma & 11847546,20 & 7776418,76 & 4071127,48 & 65,64 \\
\hline
\end{tabular}

Źródło: opracowanie własne na podstawie danych z mapy dotacji Unii Europejskiej, http://www.mapadotacji.gov.pl/ projekty?wojewodztwo=6\&powiat=\&fundusz=\&program=\&dzialanie=\&beneficjent=Kalwaria+\&tytul=\&lata=2007 [dostęp: 9.05.2018]

Tabela 4 ukazuje dofinansowanie pochodzące z Unii Europejskiej, pokrywające aż 65,6\% całych wydatków, za pomocą których zostały zrealizowane powyższe projekty. Natomiast gmina Kalwaria Zebrzydowska wniosła wkład własny w wysokości 34,4\%. Ukazuje to, iż nawet niewielkie miejscowości mogą korzystać z dofinansowań unijnych pokrywających ponad 50\% całych projektów i wspierających realizację zadań własnych.

\section{Podsumowanie}

Dzięki funduszom europejskim gmina Kalwaria Zebrzydowska pozyskała środki finansowe, za pomocą których udało się zrealizować wiele projektów mających realne znaczenie w życiu jej mieszkańców. Duże projekty, takie jak budowa hali sportowej w Kalwarii Zebrzydowskiej czy sali gimnastycznej w Przytkowicach, miały wpływ na stworzenie nowych miejsc aktywności fizycznej dla uczniów szkół tych miejscowości. Natomiast projekty „Możesz 
więcej”, „Pomóżmy sobie” czy „Przeciwdziałanie wykluczeniu cyfrowemu na terenie gminy Kalwaria Zebrzydowska" przyczyniły się do zwiększenia aktywizacji zawodowej mieszkańców i poprawy jakości ich życia. Wydaje się więc, że fundusze Unii Europejskiej istotnie wsparły gminę w realizacji jej zadań $\mathrm{i}$ - jak wynika z przeanalizowania danych z uchwał budżetowych i informacji zamieszczonych w Biuletynie Informacji Publicznej są niezbędne przy ich realizacji.

Z przeanalizowanych danych można wywnioskować, iż gmina Kalwaria Zebrzydowska dobrze wykorzystuje środki pozyskane z Unii Europejskiej. Ramy czasowe ograniczone od lat 2007-2013 ukazują jednak pewne rozbieżności. W tym okresie udział funduszy UE w dochodach bieżących gminy Kalwarii Zebrzydowskiej był wręcz niewielki - nie wynosił nawet $1 \%$. W dochodach majątkowych udział funduszy unijnych był rozbieżny, gdyż w roku 2010 wyniósł 100\%, a w kolejnych dwóch latach był równy 0\%. W 2013 roku natomiast wyniósł 20,7\%. Ukazuje to cykliczność tego typu dochodów i ich nierównomierność. Inaczej wygląda sytuacja, jeśli chodzi o dofinansowanie projektów, które gmina realizowała we własnym zakresie. Stopa współfinansowania środków z Unii Europejskiej wyniosła 65,64\%, a więc 4071 127,48 zł.

Zaprezentowane projekty były współfinansowane ze środków pochodzących z Unii Europejskiej. Największymi i najdroższymi projektami okazały się: budowa hali sportowej z zapleczem szatniowo-technicznym w miejscowości Kalwaria Zebrzydowska (1 140 000,00 zł), budowa sali gimnastycznej przy Zespole Szkół Nr 3 w Przytkowicach (1 572 997,53 zł), przeciwdziałanie wykluczeniu cyfrowemu na terenie gminy Kalwaria Zebrzydowska (1 018 206,50 zł) oraz program aktywizacji społecznej i zawodowej bezrobotnych w gminie Kalwaria Zebrzydowska (1 127 112,07 zł) - w tych czterech przypadkach wartość dotacji przekroczyła $1 \mathrm{mln}$ zł.

Należy mieć na uwadze, że przystąpienie Polski do Unii Europejskiej w 2004 roku otworzyło przed samorządami drogę do wykonywania wielu zadań, które przed tym okresem mogły być trudne do osiągnięcia z uwagi na koszty przedsięwzięć.

\section{Bibliografia}

„Biuletyn Informacji Publicznej Urzędu Miasta Kalwarii Zebrzydowskiej”, https://bip.malopolska.pl/umkalwariazebrzydowska [dostęp: 28.05.2018].

Cieślak R., Kordasiewicz J., Fundusze unijne 2007-2013. Poradnik przedsiębiorcy, Wydawnictwo Unimex, Wrocław 2007.

Główny Urząd Statystyczny, Powierzchnia i ludność w przekroju terytorialnym w 2013 r. https:// stat.gov.pl/obszary-tematyczne/ludnosc/ludnosc/powierzchnia-i-ludnosc-w-przekroju-terytorialnym-w-2013-r-,7,10.html [dostęp: 28.05.2018].

Kornberger-Sokołowska E. (red. nauk.), Zdanukiewicz J. Cieślak R., Jednostki samorzadu terytorialnego jako beneficjenci środków europejskich, Wydawnictwo Wolters Kluwer Polska, Warszawa 2012.

Mapa dotacji Unii Europejskiej, http://www.mapadotacji.gov.pl/projekty?wojewodztwo=6\&powiat $=\&$ fundusz $=\&$ program $=\&$ dzialanie $=\&$ beneficjent $=$ Kalwaria $+\&$ tytul $=\&$ lata $=2007$ [dostęp: 9.05.2018]. 
Plan rozwoju gminy Kalwaria Zebrzydowska 2004-2013, http://kalwaria-zebrzydowska.pl/ dokumenty/plan_rozwoju_lokalnego.pdf [dostęp: 1.05.2019].

Szymańska A., Fundusze unijne i europejskie 2007-2013 dla mieszkańców obszarów wiejskich, Wydawnictwo Placet, Warszawa 2008.

Szymańska A., Fundusze unijne i europejskie 2007-2013 dla samorzadu terytorialnego, Wydawnictwo Placet, Warszawa 2008.

Tylińska R., Analiza SWOT instrumentem w planowaniu rozwoju, Wydawnictwa Szkolne i Pedagogiczne, Warszawa 2005.

Wykrętowicz S., Samorzad w Polsce istota, formy, zadania, Wydawnictwo Wyższej Szkoły Bankowej, Poznań 2008.

Zieliński E., Samorzad terytorialny w Polsce, Dom Wydawniczy Elipsa, Warszawa 2004.

\section{Akty prawne}

Konstytucja Rzeczypospolitej Polskiej z dnia 2 kwietnia 1997 r., tekst jedn. Dz.U. z 2009 r. nr 114, poz. 946.

Rozporządzenie (WE) nr 1080/2006 Parlamentu Europejskiego i Rady z dnia 5 lipca 2006 r. w sprawie Europejskiego Funduszu Rozwoju Regionalnego i uchylające rozporządzenie (WE) nr 1783/1999.

Rozporządzenie (WE) nr 1081/2006 Parlamentu Europejskiego i Rady z dnia 5 lipca 2006 r. w sprawie Europejskiego Funduszu Społecznego i uchylające rozporządzenie (WE) nr 1784/1999.

Rozporządzenie Rady (WE) nr 1698/2005 z dnia 20 września 2005 r. w sprawie wsparcia rozwoju obszarów wiejskich przez Europejski Fundusz Rolny na rzecz Rozwoju Obszarów Wiejskich (EFRROW).

Rozporządzenie Parlamentu Europejskiego i Rady (UE) nr 508/2014 z dnia 15 maja 2014 r. w sprawie Europejskiego Funduszu Morskiego i Rybackiego oraz uchylające rozporządzenia Rady (WE) nr 2328/2003, (WE) nr 861/2006, (WE) nr 1198/2006 i (WE) nr 791/2007 oraz rozporządzenie Parlamentu Europejskiego i Rady (UE) nr 1255/2011.

Rozporządzenie Parlamentu Europejskiego i Rady (UE) nr 1305/2013 z dnia 17 grudnia 2013 r. w sprawie wsparcia rozwoju obszarów wiejskich przez Europejski Fundusz Rolny na rzecz Rozwoju Obszarów Wiejskich (EFRROW) i uchylające rozporządzenie Rady (WE) nr 1698/2005.

Ustawa z dnia 8 marca 1990 r. o samorządzie gminnym, tekst jedn. Dz.U. z 2019 r., poz. 506, $1309,1571,1696,1815$.

Ustawa z dnia 13 listopada 2003 r. o dochodach jednostek samorządu terytorialnego, tekst jedn. Dz.U. z 2020 r., poz. 23.

Ustawa z dnia 27 sierpnia 2009 r. o finansach publicznych, tekst jedn. Dz. U. z 2019 r., poz. 869, $1622,1649,2020$.

Wyrok Trybunału Konstytucyjnego z dnia 16 marca 1999 r., K 35/98, Orzecznictwo Trybunału Konstytucyjnego 1999, nr 3, poz. 37. 